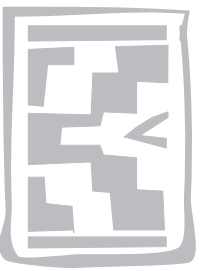

\title{
Molecular epidemiology of serotype 0 foot-and-mouth disease virus isolated from cattle in Ethiopia between 1979-2001
}

\author{
M. SAHLE ${ }^{1,2}$, E.H. VENTER ${ }^{1}$, R.M. DWARKA² and W. VOSLOO'1,2*
}

\begin{abstract}
SAHLE, M. VENTER, E.H., DWARKA, R.M. \& VOSLOO, W. 2004. Molecular epidemiology of serotype $O$ foot-and-mouth disease virus isolated from cattle in Ethiopia between 1979-2001. Onderstepoort Journal of Veterinary Research, 71:129-138

Partial 1D gene characterization was used to study phylogenetic relationships between 17 serotype O foot-and-mouth disease (FMD) viruses in Ethiopia as well as with other O-type isolates from Eritrea, Kenya, South and West Africa, the Middle East, Asia and South America. A homologous region of $495 \mathrm{bp}$ corresponding to the C-terminus end of the 1D gene was used for phylogenetic analysis. This study described three lineages, viz. African/Middle East-Asia, Cathay and South American. Within lineage I, three topotypes were defined, viz. East and West Africa and the Middle East-Asia together with the South African isolate. The Ethiopian isolates clustered as part of topotype I, the East African topotype. Two clades (based on $<12 \%$ nucleotide difference) A and $B$ were identified within the East African isolates, with clade $A$ being further classified into three significant branches, A1 (80\% bootstrap support), A2 (89\% bootstrap support) and A3 (94\% bootstrap support). Clade $B$ consisted of two Kenyan isolates. Within topotype I, the 17 Ethiopian isolates showed genetic heterogeneity between themselves with sequence differences ranging from 4.6-14\%. Lineage 2 and 3 could be equated to two significant topotypes, viz. Cathay and South America. Comparison of amino acid variability at the immunodominant sites between the vaccine strain $(E T H / 19 / 77)$ and other Ethiopian outbreak isolates revealed variations within these sites. These results encourage further work towards the reassessment of the type $O$ vaccine strain currently being used in Ethiopia to provide protection against field variants of the virus.
\end{abstract}

Keywords: Ethiopia, Foot-and-mouth disease virus, serotype $\mathrm{O}$

\section{INTRODUCTION}

Ethiopia is one of the countries in Africa with huge livestock resources that play a crucial role in the livelihoods of the majority of Ethiopians. Animal rearing is an integral part of the agricultural production in Ethiopia with the livestock population comprising

* Author to whom correspondence is to be directed. E-mail: wilna@saturn.ovi.ac.za

1 Department of Veterinary Tropical Diseases, University of Pretoria, Private Bag X04, Onderstepoort, 0110 South Africa

2 Onderstepoort Veterinary Institute, Exotic Diseases Division, Private Bag X05, Onderstepoort, 0110 South Africa

Accepted for publication 10 November 2003-Editor approximately 20.7 million cattle and 37.9 million sheep and goats (McDermott \& Arimi 2002). Animals also represent the major draught power (95\%) for crop production. The agricultural sector constitutes approximately $45 \%$ of the gross domestic product (GDP), more than $90 \%$ of foreign exchange earnings, $85 \%$ of employment opportunities and most of the domestic food supply (Anon. 1998, 2000).

Despite the large numbers of animals, the rewards derived from livestock production are below expectations due to various constraints such as poor genetic potential of animals, lack of proper livestock management and prevalent livestock diseases. Animal diseases are currently widespread in all agro-ecological zones of the country and mortality 
losses due to diseases are estimated to be $8-10 \%$, $15 \%$ and $12 \%$ for cattle herds and sheep and goat flocks respectively. It is estimated that animal diseases reduce the production and productivity of livestock by 50-60\% per year (Anon. 1998).

Foot-and-mouth disease (FMD) is at present one of the major livestock diseases of socio-economic importance in the country. Previously, FMD occurred frequently in pastoral herds in the lowland areas of Ethiopia (Haile Yesus 1988) but in recent years the incidence of the disease had increased and become apparent in the highland areas, where $80 \%$ of the total livestock population is present (Mengistu 1997; Anon. 2000). The Animal Health Division of the Ministry of Agriculture of Ethiopia reported in 2000 that the incidence of FMD has increased 1.31.5 fold since 1990 . The higher incidence of the disease may be associated with extensive movement of livestock and the high rate of contact between animals at commercial markets, common grazing areas and watering points (Mersie, Tafesse, Getahun \& Teklu 1992; Anon. 1998).

Six of the seven serotypes of FMD virus have been recorded in Africa and are endemic to most countries in sub-Saharan Africa, with the exception of a number of southern African countries where the disease is controlled by strict measures such as movement control and vaccination (Kitching 1998; Brückner, Vosloo, Du Plessis, Kloeck, Connoway, Ekron, Weaver, Dickason, Schreuder, Marais \& Mogajane 2002; Vosloo, Bastos, Sangare, Hargreaves \& Thomson 2002; Thomson, Vosloo \& Bastos 2003). The three SAT serotypes are endemic to most African buffalo (Syncerus caffer) populations in subSaharan Africa (Hedger 1972, 1976; Hedger, Condy \& Golding 1972; Hedger, Forman \& Woodford 1973; Condy, Hedger, Hamblin \& Barnett 1985; Thomson 1996, 2001; Thomson et al. 2003) and outbreaks in domestic animals and other wildlife species due to these serotypes can often be traced to buffalo movement and contact (Dawe, Flanagan, Madekurozwa, Sorensen, Anderson, Foggin, Ferris \& Knowles 1994; Vosloo, Bastos, Kirkbride, Esterhuysen, Van Rensburg, Bengis, Keet \& Thomson 1996; Bastos, Boshoff, Keet, Bengis \& Thomson 2000). Foot-andmouth disease outbreaks caused by serotype $O$ and $A$ are unusual in southern Africa, but occur frequently elsewhere on the subcontinent (Vosloo et al. 2002) but it is not known whether these serotypes have become established in buffalo herds in close proximity of these outbreaks.

The role of wildlife in the epidemiology of FMD in Ethiopia has not been investigated in detail, but it is accepted that the disease is maintained mostly in a domestic cycle. During the period 1957/73, 62 outbreaks of serotype $O, 24$ of serotype $C$ and 12 of serotype A occurred. Comparisons based on virus neutralization and serum precipitation tests between the European and Ethiopian serotypes $\mathrm{A}, \mathrm{O}$ and $\mathrm{C}$ indicated that the Ethiopian serotype $A$ isolates were distinct from the European type A viruses, while the differences between the European and Ethiopian serotypes $\mathrm{O}$ and $\mathrm{C}$ isolates were negligible (Martel 1974; Martel \& Gallon 1975). Following this period, until 1992, FMD outbreaks due to serotypes $O$ and A were common while serotype $C$ viruses seemed to disappear (Berson, Colson, Fikre, Vigier, Assefa, Guerche, Blanc \& Prunet 1972; Fikre 1975; Anon. 1976; Haile Yesus 1988; Roeder, Abraham, Mebratu \& Kitching 1994). The presence of SAT-2 viruses in Ethiopia was first reported by Roeder et al. in 1994 although SAT-2 is commonly found in southern and eastern Africa (Thomson 1994; Bastos \& Sangare 2001; Vosloo et al. 2002). Between 1990 and 1999, 42 outbreaks due to serotype O, 13 due to serotype A and six SAT-2 outbreaks were reported in Ethiopia. It seems therefore that serotype $\mathrm{O}$ FMD outbreaks are more prevalent and have been one of the major causes for considerable economic losses for the rural communities in Ethiopia.

Despite the widespread distribution and economic impact of FMD in Ethiopia, minimal clinical and serological studies have been reported by the Regional Veterinary Laboratories and the National Animal Health Institute in Ethiopia (Anon. 1998). The disease is accepted as endemic and the only attempt to date by the Department of Agriculture in Ethiopia to control the disease is by limited vaccination campaigns in dairy herds.

The epidemiology of circulating viruses as well as their genetic relationships to the vaccine strain is lacking. In this study an attempt was made to elucidate the genetic variation among Ethiopian serotype O viruses isolated during the period 1977-2001 and to compare their relationships with other published serotype O FMD virus isolates as well as with the type $O$ vaccine strain $(E T H / 19 / 77)$ currently being used in the vaccine produced in Ethiopia.

\section{MATERIALS AND METHODS}

\section{Viruses studied}

The serotype O outbreak strains of 2001 (ETH15/01, ETH16/01 and ETH 22/01) were first propagated from clinical material onto primary pig kidney (PK) 
cells and then passaged on IB-RS-2 (Instituto Biologico Rim Suino) cells. All other isolates from Ethiopia and Eritrea isolated between the years 1979-1996 were supplied by the World Reference Laboratory (WRL) for FMD at the Institute for Animal Health, Pirbright (UK). These isolates were stored at $-70{ }^{\circ} \mathrm{C}$ for protracted periods of time and were therefore propagated on IB-RS-2 cells prior to further processing. The laboratory designation, sampling date and geographical origin of all isolates are indicated in Table 1.

\section{Nucleic acid isolation and RT-PCR amplification}

RNA was extracted from tissue culture samples using a silica/guanidium thiocyanate method (Boom,
Sol, Salimans, Jansen, Wertheim-van Dillen, Van den Noordaa 1990) and reverse transcribed using AMV reverse transcriptase (Promega) and the antisense primer $\mathrm{P} 1$

(5'-GAAGGCCCAGGGTTGGACTC-3') (Beck \& Strohmaier 1987) as described previously (Bastos 1998).

The $\mathrm{P} 1$ primer in combination with the serotype $\mathrm{O}$ specific sense primer $\mathrm{VP}_{1} \mathrm{O}$

(5'-GATTTGTGAAGGTGACACC-3') (Rodriguez, Nunez, Nolasco, Ponz, Sobrino \& De Blas 1994) were used to amplify a $581 \mathrm{bp}$ fragment of the 1D gene (VP1). The PCRs were performed in $50 \mu \ell$ volumes in the presence of $3 \mu \ell$ of cDNA, $25 \mathrm{pmol}$ of each primer ( $\mathrm{VP}_{1} \mathrm{O}$ and $\left.\mathrm{P} 1\right), 200 \mu \mathrm{M}$ dNTPs, 1X

TABLE 1 Summary of serotype $O$ foot-and-mouth disease viruses included in this study and that were compared with those published in the literature

\begin{tabular}{|c|c|c|c|c|}
\hline Virus designations & Sampling year & Country of origin & Reference & Genbank accession no. \\
\hline * 1. ETH/1/79 & 1979 & Ethiopia & This study & AY283376 \\
\hline * 2. $E T H / 3 / 79$ & 1979 & Ethiopia & This study & AY 283377 \\
\hline - $\quad$ 3. ETH 19/77 & 1983 & Ethiopia & This study & AY283378 \\
\hline * 4. ETH/3/90 & 1990 & Ethiopia & This study & AY283379 \\
\hline * 5. ETH/8/90 & 1990 & Ethiopia & This study & AY283380 \\
\hline * 6. ETH/12/90 & 1990 & Ethiopia & This study & AY283381 \\
\hline * 7. ETH/9/92 & 1992 & Ethiopia & This study & AY283382 \\
\hline * 8. ETH/2/93 & 1993 & Ethiopia & This study & AY283383 \\
\hline * 9. ETH/8/94 & 1994 & Ethiopia & This study & AY283384 \\
\hline * 10. ETH/24/94 & 1994 & Ethiopia & This study & AY283385 \\
\hline * 11. ETH/30/94 & 1994 & Ethiopia & This study & AY283386 \\
\hline * 12. ETH/1/95 & 1995 & Ethiopia & This study & AY283387 \\
\hline * 13. ETH/5/95 & 1995 & Ethiopia & This study & AY283388 \\
\hline * 14. ETH/3/96 & 1996 & Ethiopia & This study & AY283392 \\
\hline ** 15. ETH/15/01 & 2001 & Ethiopia & This study & AY283393 \\
\hline ** 16. ETH/16/01 & 2001 & Ethiopia & This study & AY283394 \\
\hline ** 17. ETH/22/01 & 2001 & Ethiopia & This study & AY283395 \\
\hline * 18. ERI/1/96 & 1996 & Eritrea & This study & AY283390 \\
\hline * 19. ERI/2/96 & 1996 & Eritrea & This study & AY283391 \\
\hline 20. KEN/77/78 & 1978 & Kenya & Sangare et al. 2001 & AF300812 \\
\hline 21. KEN/10/95 & 1995 & Kenya & Samuel \& Knowles 2001 & AJ303514 \\
\hline 22. GHA/5/93 & 1993 & Ghana & Sangare et al. 2001 & AF300806 \\
\hline 23. $\mathrm{GHA} / 6 / 93$ & 1993 & Ghana & Sangare et al. 2001 & AF300807 \\
\hline 24. $\mathrm{GHA} / 9 / 93$ & 1993 & Ghana & Sangare et al. 2001 & AF300809 \\
\hline 25. BFK/1/92 & 1992 & Burkina Faso & Sangare et al. 2001 & AF300804 \\
\hline 26. ALG/1/99 & 2000 & Algeria & Sangare et al. 2001 & - \\
\hline 27. SAU/100/94 & 1994 & Saudi Arabia & Samuel et al. 1997 & AJ004660 \\
\hline 28. BAN/1/97 & 1997 & Bangladesh & Freiberg et al. 1999 & - \\
\hline 29. IRQ/30/2000 & 2000 & Iraq & Samuel \& Knowles 2002 & AJ303499 \\
\hline 30. SAR/15/2000 & 2000 & South Africa & Sangare et al. 2001 & AF306647 \\
\hline 31. O5India & 1962 & India & Sangare et al. 2001 & AF274297 \\
\hline 32. O1Manisa & 1969 & Turkey & Unpublished & AJ251477 \\
\hline 33. Moscow/95 & 1995 & Russia & Unpublished & AJ004662 \\
\hline 34. Taiwan/97 & 1997 & Taiwan & Tsai et al. 1999 & AF026168 \\
\hline 35. Taiwan/98 & 1998 & Taiwan & Tsai et al. 1999 & AF095877 \\
\hline 36. O1 Yrigoyen & 1982 & Argentina & Saiz et al. 1993 & Z21862 \\
\hline
\end{tabular}

- Vaccine strain (isolation date is 1977 according to the Ethiopian calendar, but 1983 according to the Gregorian calendar)

* Viruses supplied by the World Reference Laboratory

** Viruses isolated from FMD outbreaks in Ethiopia 
Taq buffer and $2.5 \mathrm{U}$ of Taq polymerase (Roche) using a thermal cycling profile of 39 cycles of denaturation at $96^{\circ} \mathrm{C}$ for $12 \mathrm{~s}$, annealing at $53^{\circ} \mathrm{C}$ for $20 \mathrm{~s}$ and extension at $70^{\circ} \mathrm{C}$ for $40 \mathrm{~s}$.

\section{DNA purification and cycle sequencing}

PCR products of $581 \mathrm{bp}$ were excised from a $1.5 \%$ agarose gel and purified using the Qia Quick Gel Extraction Kit (Qiagen). Purified PCR products were sequenced using the Big Dye ${ }^{\circledR}$ version 3.0 Cycle Sequencing kit and the $\mathrm{ABI}$ Prism 310 Genetic Analyser (Applied Biosystems). Two independent sequencing reactions were performed per sample using the sense and antisense primers used in the PCRs.

\section{Data analysis}

Nucleotide sequences generated were aligned using DAPSA (Harley 2001). A homologous region of $495 \mathrm{bp}$ corresponding to the C-terminus end of the 1D gene was used for phylogenetic analysis. Nucleotide sequences of serotype $\mathrm{O}$ isolates from West, South Africa, the Middle East, Asia and South America were included to deduce the phylogeny of this serotype on the African continent and to put the study in a global perspective. Phylogenetic trees were constructed using the Unweighted Pair Group Mean Average (UPGMA) method included in MEGA 2.0 (Kumar, Tamura, Jakobsen \& Nei 2001) and the pattern of topology was also evaluated with Neighbor Joining (NJ) and Maximum Parsimony methods, whilst the confidence levels were assessed by 1000 bootstrap replications. The average genetic distances between genotypes were also estimated by pair-wise comparison of the arithmetic means of all pair-wise distances between taxa in the inter-group comparison. An amino acid variability plot (Kumar, Tamura \& Nei 1993) identified hypervariable regions within the partial VP1 protein between all isolates included in the study.

\section{RESULTS}

\section{Phylogenetic relationships among serotype 0 isolates from Ethiopia and previously studied regions}

The UPGMA tree (Fig. 1) derived by comparison of 495 nucleotide sequences at the 3' end of the 1D gene of 36 viruses showed that the serotype $O$ isolates clustered into five distinct topotypes, designated I-V. Identical topotype distributions were consistently recovered with all methods included in MEGA that were used to construct the phylogenetic tree, indicating that a true phylogeny is reflected in Fig. 1. The cut-off value for topotypes ( $>14 \%$ nucleotide difference between clades) was compared with previous studies and gave a similar number of topotypes as described previously (Samuel \& Knowles 2001; Sangare, Bastos, Marquardt, Venter, Vosloo \& Thomson 2001) and can be summarised as follows:

$\begin{array}{ll}\text { Topotype I: } & \text { East Africa } \\ \text { Topotype II: } & \text { Middle East- South Asia } \\ \text { Topotype III: } & \text { West Africa } \\ \text { Topotype IV: } & \text { Cathay } \\ \text { Topotype V: } & \text { South America }\end{array}$

Topotype I comprised 21 isolates of East African origin. Within topotype I, two significant clades, viz. $A$ and $B$, differing by $13 \%$ from each other were identified. Clade A contained isolates from Ethiopia and Eritrea, while clade B contained the two isolates from Kenya. Clade $A$ was divided into three significant branches (A1-A3) supported by bootstrap values of $\geq 80 \%$ and $\leq 10 \%$ sequence identity within the branch, indicating that isolates within these branches probably belonged to the same epizootics. Branch A1 comprised of Ethiopian isolates isolated over a period of 18 years (1983-2001) and a single Eritrean isolate from 1996. This branch also contained the vaccine strain ETH/19/77 which differed by $4.6 \%$ from its nearest neighbour, ETH/5/95 (Fig. 1). Branch A2 comprised solely of Ethiopian isolates spanning 13 years (1979-1992), while two Ethiopian isolates from 1994 and 1996 and a single Eritrean isolate from 1996 constituted the third significant branch, A3.

Clade B, within topotype I, consisted of viruses isolated during 1978 and 1995 from Kenya and is supported by a bootstrap value of $100 \%$ (Fig. 1). These two isolates demonstrated a surprisingly close genetic relationship although they were isolated 17 years apart. Topotypes II-V have been described in previous studies (Samuel \& Knowles, 2001; Sangare et al. 2001) and served only for comparative purposes in this study. Topotype II consisted of isolates from the Middle-East South Asia and the South African isolate, while topotype III consisted of West African isolates. Topotypes IV and V consisted of representatives from the Cathay and South American lineages, respectively (Fig. 1).

\section{Amino acid variability}

Alignment of the deduced amino acid sequences of all 36 viruses included in this study demonstrated 
M. SAHLE et al.

FIG. 1 UPGMA tree depicting genetic relationships of serotype O FMD viruses from Ethiopia, Middle East, Asia, West and South Africa. 1-3 and I-V indicate the major lineages and topotypes, respectively, while the significant clades are indicated by $\mathrm{A} 1-\mathrm{A} 3$ and $\mathrm{B}$. * denotes vaccine strain

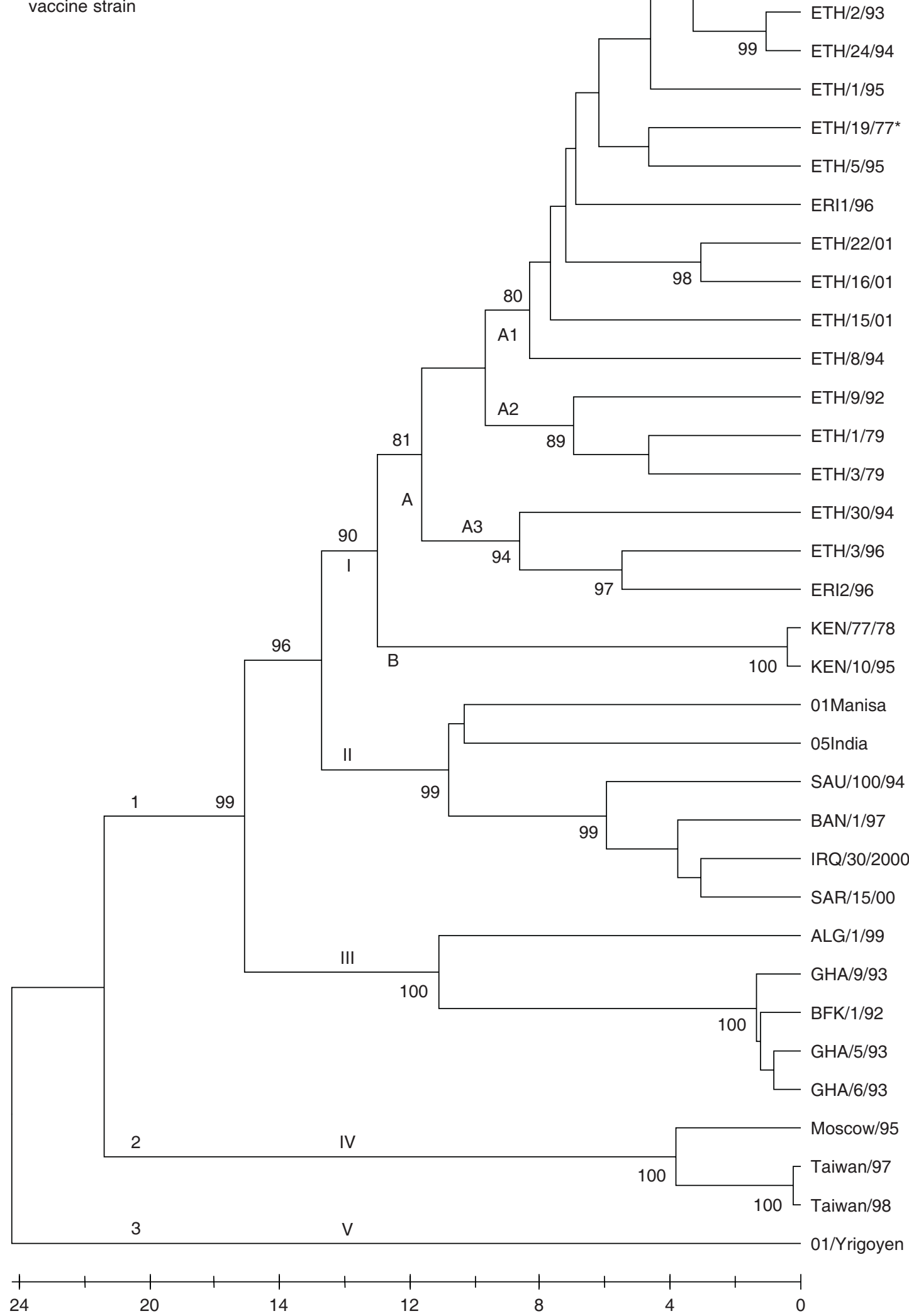


Serotype O foot-and-mouth disease virus from cattle in Ethiopia

\begin{tabular}{|c|c|c|c|c|c|c|c|c|c|c|}
\hline & 58 & 68 & 78 & $8 \varepsilon$ & 8 & 98 & \multirow{2}{*}{\multicolumn{2}{|c|}{$\begin{array}{r}108 \\
\text { DNTTNPTAYH }\end{array}$}} & \multirow{2}{*}{$\begin{array}{r}118 \\
\text { KAPLTRLALP }\end{array}$} & 128 \\
\hline ETH/19/77 & YVLDLMQTPA & HTLVGALLRT & ATYYFADLEV & $J$ AVKHKGDLTV & \multicolumn{2}{|c|}{ VPNGAPESAL } & & & & YTAPHRVLAT \\
\hline $\mathrm{ETH} / 8 / 90$ & $\ldots$ & $\ldots \ldots$ & $\ldots \ldots$ & KE.N. & \multirow{2}{*}{\multicolumn{2}{|c|}{${ }^{\ldots} \ldots \ldots$}} & & & $\ldots \ldots \ldots$ & $\ldots \ldots$ \\
\hline $\mathrm{ETH} / 3 / 90$ & $\ldots$ & $\ldots$ & $\ldots \ldots \ldots$ & ...E.N. & & & . & & $\ldots \ldots \ldots$ & \\
\hline ETH/5/95 & $\ldots$ & $\ldots \ldots \ldots \ldots$ & $\ldots \ldots \ldots \ldots$ & KE.N. & \multicolumn{2}{|l|}{$\cdots \cdots \cdots \cdots$} & $\ldots \ldots$ & . & $\ldots \ldots \ldots \ldots$ & $\ldots$ \\
\hline $\mathrm{ETH} / 12 / 90$ & & $\ldots$ & $\ldots \ldots \ldots$ & KE.N. & & & & & & \\
\hline $\mathrm{ETH} / 2 / 93$ & ?.. & Q... & & . KE.N. & & & & & & \\
\hline $\mathrm{ETH} / 1 / 95$ & & & & ...E.N. & & & & & & \\
\hline $\mathrm{ETH} / 24 / 94$ & н.. & $\ldots$ & & ...E.N. & .. & & & & .. & \\
\hline ERI1/96 & & $\ldots$ & & ...E.N. & & & & & & \\
\hline ETH/22/01 & .L... & & & ...E.N. & & & & & & \\
\hline $\mathrm{ETH} / 16 / 01$ & A. . . L . . & & & ... & & & & & & \\
\hline ETH/15/01 & H......... & & & ......N. & .. & & & & .. & \\
\hline $\mathrm{ETH} / 8 / 94$ & & & & ...E.N. & & & & & & \\
\hline $\mathrm{ETH} / 1 / 79$ & N. . & & & ...E.N. & & & & & & \\
\hline $\mathrm{ETH} / 3 / 79$ & & $\ldots \ldots \ldots \mathrm{A}$ & & E.N. & & & & & & \\
\hline ЕTH/9/92 & $\ldots \ldots \ldots$ & ч $\ldots \ldots \ldots$ & $\ldots \ldots$ & . WE.N. & $\ldots \ldots \ldots$ & & $\ldots \ldots$ & & $\ldots$ & $\ldots \ldots \ldots$ \\
\hline $\mathrm{ETH} / 30 / 94$ & $\ldots \ldots \ldots$ & $\ldots \ldots \ldots$ & $\ldots \ldots \ldots \ldots$ & ...E.N... & ${ }_{1} \ldots \mathrm{T}_{\mathrm{s}}$ & & & & $\ldots$ & $\ldots \ldots$ \\
\hline $\mathrm{ETH} / 3 / 96$ & & & & WE.N... & . $\quad \ldots \ldots \mathrm{TV}$ & & N... & & $\ldots$ & \\
\hline ERI2/96 & н. ...... & $\ldots$ & $\ldots \ldots$ & WEEN... & - W A & & $\ldots \ldots$ & & $\ldots$ & $\ldots \ldots$ \\
\hline $\mathrm{KEN} / 77 / 78$ & N......... & $\ldots \ldots \ldots \ldots$ & $\ldots \ldots \ldots$ I. & . ...E.N. & $\quad \ldots \ldots \ldots$ & & $\ldots \ldots$ & & $\ldots \ldots$ & $\ldots \ldots \ldots$ \\
\hline $\mathrm{KEN} / 10 / 95$ & & $\ldots \ldots \ldots$ & $\ldots \ldots \ldots$ I. & . ...E.N. & & & $\ldots \ldots$ & & $\ldots \ldots$ & $\ldots \ldots \ldots \ldots$ \\
\hline OlManisa & N......... & $\ldots \ldots \ldots$ & $\ldots \ldots \ldots$ & . WE.N. & - W... & & & & & $\ldots \ldots$ \\
\hline O5India & N......... & $\ldots \ldots \ldots \ldots$ & $\ldots \ldots \ldots \ldots$ & . _..E.N. & . & & $\ldots \ldots$ & $\ldots$ & $\ldots \ldots$ & $\ldots \ldots \ldots$ \\
\hline $\mathrm{BAN} / 1 / 97$ & $\mathrm{~N} \ldots \ldots \ldots$ & $\ldots \ldots \ldots$ & $\ldots \ldots \ldots$ & . KE.N. & . $\ldots \ldots$ т. & & $\ldots \ldots$ & & & $\ldots \ldots \ldots$ \\
\hline $\operatorname{IRQ} / 30 / 2000$ & N... & & $\ldots \ldots \ldots$ & . KE.N. & ….. & & & & & $\ldots$ \\
\hline $\mathrm{SAR} / 15 / 00$ & N.......... & $\ldots$ & $\ldots \ldots \ldots$ & . WE.N. & …. & & & & & \\
\hline $\mathrm{ALG} / 1 / 99$ & N......... & $\ldots \ldots \ldots$ & $\ldots \ldots \ldots$ & . ...Е. & ….. & & $\ldots$ & $\ldots$ & $\ldots$ & ?... \\
\hline $\mathrm{GHA} / 9 / 93$ & N......... & $\ldots$ & $\ldots \ldots \ldots$ & . …E. & & & & & & \\
\hline GHA $/ 6 / 93$ & N......... & $\ldots$ & $\ldots \ldots \ldots$ & . ...E. & ...... K. & & & & & \\
\hline GHA / $5 / 93$ & N........ & & & . . . E. & ....... K. & & & & & \\
\hline $\mathrm{BFK} /$ & N......... & & & …E. & & & & & & \\
\hline $\mathrm{SAU} / 100 / 94$ & T.?... K... & & & ...E.N. & ... & & & $\ldots \mathrm{R}$ & ?. & .R. \\
\hline Moscow/95 & N........ & & $\ldots$....LL & L ...E. & $\ldots$. & & & & .E. & \\
\hline Tail & $\ldots$. I. & & ..S...L & E. & . T. & & & & .E. & \\
\hline Taiwan/98 & ...I. & & ..S...L & L W.E. & . T. & & & & .E. & \\
\hline O1/Yrigoyen & NT.....I.S & … & S...S.I & I V...E. & . . . . VK. & & $\mathrm{G} \ldots \ldots$ & $\cdots Y$ & K. & $\ldots$ у... \\
\hline & & G-H loop & & & & & & & & C-terminus \\
\hline & 138 & 148 & 158 & 168 & 178 & & 188 & & 198 & \\
\hline ЕТН/19/77 & TYNGNCKYGE & TSVTNVRGDL & QVLAQKAVRP I & LPTSFNYGAI & KATRVTELLY & RMKL & RAETYCP & RPLL & AIHPSE ARHK & CRIVAPVKQLL \\
\hline ETH/ & $\mathrm{V} \ldots \ldots \ldots$ & $\ldots \ldots \ldots$ & ....A.A & $\ldots \ldots \ldots$ & $\ldots \ldots \ldots$ & $\ldots$ & ........ & $\ldots$ & $\ldots \ldots \ldots$ & $\ldots \ldots \ldots \ldots$ \\
\hline $\mathrm{ETH} / 3 / 90$ & v.......... & $\ldots \ldots \ldots$ & $\ldots \ldots$ А.А & $\ldots \ldots \ldots$ & $\ldots \ldots \ldots$ & & $\ldots \ldots$ & & $\ldots \ldots \ldots$ & .......... \\
\hline $\mathrm{ETH} / 5 / 95$ & v... & $\ldots \ldots \ldots$ & 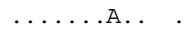 & $\ldots \ldots \ldots$ & $\ldots \ldots \ldots$ & & $\ldots \ldots$ & & $\cdots$ & . \\
\hline ETH/ & V.. & $\ldots$ & .....A.A & $\ldots \ldots \ldots$ & nan & & $\ldots$ & & $\ldots \ldots$ & .. \\
\hline $\mathrm{ETH} / 2 / 93$ & v.......... & $\ldots \ldots \ldots$ & …A.A & $\ldots \ldots \ldots$ & n...... & & $\ldots \ldots$ & & $\ldots \ldots \ldots$ & $\ldots \ldots \ldots$ \\
\hline ETH/1/95 & $\ldots$ & $\ldots$ & $\ldots \ldots$ A.A & $\ldots \ldots \ldots$ & $\ldots \ldots \ldots$ & & $\ldots \ldots$ & & $\ldots \ldots \ldots$ & $\ldots \ldots$ \\
\hline ETH/24/94 & v... & $\ldots$ & \#\#A.А & .......... & n....... & & $\ldots \ldots$ & & ....... & $\ldots$ \\
\hline ERI1/96 & V....R... & .P. . & ...VVA.T & $\ldots$ & $\ldots$ & & $\ldots$ & .. & .. $\quad .$. & $\ldots$ \\
\hline $\mathrm{ETH} / 22 / 01$ & V.. & .P. & …A.A & $\ldots \ldots \ldots$ & & & & & . $\quad .$. & .. \\
\hline $\mathrm{ETH} / 16 / 01$ & $\mathrm{v}$ & .P. & $\ldots \ldots \ldots A$ & $\ldots$ & & .. & & . & . . . & . M...?.... \\
\hline ETH/15/01 & $\mathrm{v}$ & .P. & $\ldots \ldots$ VA.T & & & & & & . & \\
\hline $\mathrm{ETH} / 8 / 94$ & & .P. & .....VA.T & $\ldots$ & & $\therefore$ & & & $\ldots . \mathrm{K}$ & \\
\hline $\mathrm{ETH} / 1 / 79$ & $\mathrm{~V} \ldots \mathrm{D} \ldots \mathrm{K}$ & AP. & $\ldots \ldots \mathrm{T}_{\mathrm{T}}$ & & & & & & & \\
\hline $\mathrm{ETH} / 3 / 79$ & V....R... & A & ….А. Т & & & & & & 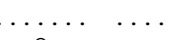 & \\
\hline ETH/9/92 & V...K.R... & A & $\ldots \ldots$ A.A & & & & & & $\ldots Q \ldots$ & \\
\hline $\mathrm{ETH} / 30 / 94$ & V....R... & & $\ldots \ldots$ VA.T & & & & & & $\ldots$. & \\
\hline $\mathrm{ETH} / 3 / 96$ & V...S...K & A & ..... AWT & $\ldots$ & & & $\cdots$ & & …k. & . \\
\hline ERI2/96 & V....R... & A & \#\#А.Т & $\ldots$ & $\ldots \ldots \ldots$ & & $\ldots$ & & …т. $\quad \ldots$ & \\
\hline $\mathrm{KEN} / 77 / 78$ & $\mathrm{~V} \ldots \ldots \mathrm{R} \ldots \mathrm{R}$ & & …А. T & $\cdots$ & $\ldots \ldots$ I.... & & & & T... & R...A. \\
\hline $\mathrm{KEN} / 10 / 95$ & $\mathrm{~V} \ldots \ldots \mathrm{R} . \mathrm{R}$ & $\ldots$ & ‥АА T & $\ldots \ldots \ldots$ & $\ldots \ldots$ I... & & $\ldots \ldots$ & $\ldots$ & т... & .R.I.A. . . \\
\hline O1Manisa & $\mathrm{V} \ldots \ldots \ldots \mathrm{D}$ & GT.A. . & …A.А & $\ldots \ldots \ldots$ & $\ldots \ldots \ldots$ & & $\ldots \ldots$ & & $\ldots$... & $\ldots \ldots \ldots$ \\
\hline O5India & $\mathrm{V} \ldots \ldots \ldots \mathrm{AD}$ & GP.A...... & …A & $\ldots \ldots \ldots$ & $\ldots \ldots \ldots$ & & ....... & & $\ldots \ldots \ldots$ & \\
\hline $\mathrm{BAN} / 1 / 97$ & $\mathrm{v} \ldots \ldots \ldots$ & $\ldots$ & …т.т & $\ldots \ldots \ldots$ & nank & & ....... & & $\ldots \ldots \ldots$ & ........ \\
\hline $\operatorname{IRQ} / 30 / 200$ & v.... & SP........ & \#.АА Т & $\ldots \ldots \ldots$ & $\ldots \ldots \ldots$ & & $\ldots \ldots$ & & $\ldots \ldots \ldots$ & $\ldots \ldots \ldots \ldots$ \\
\hline $\mathrm{SAR} / 15 / 00$ & & & ...А. T & $\ldots$ & $\ldots \ldots \ldots$ & & $\ldots \ldots$ & & $\ldots \ldots \ldots$ & \\
\hline $\mathrm{ALG} / 1 / 99$ & V...S.R.SG & AVTP...... & ...RR.APM & .....F. & ........ & & $\ldots \ldots$ & & F.... & $\cdots$ \\
\hline $\mathrm{GHA} / 9 / 93$ & V...S...SR & VE.PKL. . . & ‥RR.A.T & $\ldots \ldots F \ldots$ & & & & & V...T T. & \\
\hline $\mathrm{GHA} / 6 / 93$ & V...S...SR & VE.PK..... & ...RR.A.T & $\ldots \ldots F \ldots$ & & & & & $\begin{array}{ll}\text { V.... T.R. } \\
\text { T. }\end{array}$ & R....M. \\
\hline GHA $/ 5 / 93$ & V...s...SR & & $\ldots$.RR.A.T & ....F. F. & & & 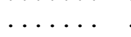 & & V.... T.R. & .......... \\
\hline $\mathrm{BFK} / 1 / 92$ & V...S...SR & VE.PK..... & W..R.A.T & $\ldots \ldots F \ldots$ & . & & $\ldots$ & & .V... T. & ........ \\
\hline $\mathrm{SAU} / 100 / 94$ & & SC. . & …... & $\ldots \ldots \ldots \ldots$ & & & & & $\ldots \ldots$ & \\
\hline Moscow/95 & V...SS ...D & $\ldots \mathrm{TN}$ & .Е.T & $\ldots \ldots \ldots$ & & & & & $\ldots Q \ldots D$ & $\ldots ? \mathrm{~A}$ \\
\hline Taiwan/97 & V...SS ...D & . .TN. & …Е.Т & $\ldots \ldots \mathrm{F}$ & & & & & $\ldots Q \ldots D \quad \ldots$ &. R. .A. . . \\
\hline Taiwan/98 & V...SS ...D & $\ldots \mathrm{TN} \ldots \ldots$ & _....Е.T & $\ldots \ldots F \ldots$ & & & . & & $\ldots Q \ldots D \quad \ldots$ &.$R \ldots$...... \\
\hline 01/Yrigoyen & V...E.T.SS & NA.P. . . P & NL.E. .A.M & . AY. & & & & & $\ldots \ldots$ TD $\ldots$ & R. . . . RT. \\
\hline
\end{tabular}

FIG. 2 Sequence alignment of 165 amino acids from the C-terminal end of the 1D gene of 36 type O FMD viruses. The main immunodominant regions are indicated in bold. Cell attachment site (RGD) in the GH-loop of the viruses, at position 145147 , is underlined. Dots (.) indicate amino acids identical to the vaccine strain ETH/19/77. '?' indicates amino acids that could not be determined due to nucleotide sequence ambiguities 
that $103 / 165(62.42 \%)$ of amino acid sites were conserved over the region investigated (Fig. 2), while $250 / 495(50.51 \%)$ of nucleotide sequences were conserved (data not shown) which correlated well with that reported by Sangare et al. (2001). Variability in amino acid sites occurred predominantly in two distinct regions comprising the G-H loop (amino acid positions 133-158) and the C-terminus (amino acid positions 194-213), known to be the main antigenic sites of VP1 (Kitson, McCahon \& Belsham 1990). The RGD cell attachment site (amino acids position 145-147) within the GH-loop of the gene was conserved in all isolates. The amino acid variability plot also showed that the two immunodominant sites, G-H loop and C-terminus, are hypervariable in their amino acid composition, but the G-H loop has more hypervariable sites compared to the C-terminus.

A total of 24 amino acid site changes were observed in Ethiopian isolates in relation to the vaccine strain (ETH/19/77) (Fig. 2). Within the G-H loop, at position 155 most of the isolates, including the vaccine strain, contained an A while the recent Ethiopian isolate $\mathrm{ETH} / 15 / 01$, an Eritrean isolate (ERI/1/96) and two 1994 isolates ETH/8/94 and ETH/30/94 had a V. At position 83, all isolates with the exception of $E T H / 15 / 01$ and $E T H / 16 / 01$ showed a change from $\mathrm{K}$ to $\mathrm{E}$ in comparison to the vaccine strain, ETH/19/77. Similarly, all isolates at position 129 had a $V$ except for the vaccine strain which had a $T$. Comparison of variable sites at the $\mathrm{C}$-terminus end of all the Ethiopian isolates revealed only 5 amino acid mutations (Fig. 2). A recent Ethiopian isolate, ETH/16/01 showed a change from $\mathrm{I} \rightarrow \mathrm{M}$ at position 205. Amino acids changes of $\mathrm{S} \rightarrow \mathrm{T}$ and $\mathrm{S} \rightarrow \mathrm{K}$ were observed at position 197 for two Ethiopian isolates, $\mathrm{ETH} / 30 / 94$ and $\mathrm{ETH} / 3 / 96$ respectively, while one isolate, ETH/8/94, showed an amino acid change of $\mathrm{E} \rightarrow \mathrm{K}$ at position 198 . This study revealed that the type O FMD virus population circulating in Ethiopia, Eritrea and Kenya are heterogeneous in their amino acid composition (Fig. 2).

\section{DISCUSSION}

Foot-and-mouth disease is enzootic in Ethiopia as in most parts of Africa and only a few countries in the south and north of the continent have managed to control the disease and have access to lucrative export markets for live animals and animal products. In Ethiopia, factors such as the presence of high numbers of susceptible animals, wild and domestic animals sharing common grazing pastures and watering points in areas where wildlife occur, as well as lack of control of animal movement contribute to the occurrence of FMD outbreaks and to the difficulty in controlling the disease. An investigation into the molecular epidemiology of the FMD viruses circulating in Ethiopia will provide further insights into the epidemiology of the disease and the genetic relationships between the virus strains of recent outbreaks and will assist with the planning of control strategies.

Samuel \& Knowles (2001) identified eight serotype O topotypes across the world, while Sangare et al. (2001) described seven genotypes of serotype $O$ viruses in their study. Subsequently, in 2003, Knowles \& Samuel equated these genotypes to their topotype classification concept in their review of the molecular epidemiology of FMDV. The present study focussed on Ethiopia only, where 19 isolates from Ethiopia and Eritrea were compared to 17 other viruses representing topotypes that were previously described (Sangare et al. 2001), thus the limited number of topotypes recovered with our data. For a universal appeal the results in this study will be discussed according to the topotype concept. Phylogenetic analysis showed that the Ethiopian, Eritrean as well as the vaccine strain clustered as clade A, supported by $81 \%$ bootstrap value, while the two Kenyan isolates clustered as part of clade B, supported by $100 \%$ bootstrap value. However, both clades, A and B, clustered to form topotype I, an East African topotype. The clustering profiles showed close genetic relationships between viruses in countries with common boundaries as is demonstrated by the grouping of Eritrean and Ethiopian viruses in clades A1 and A3. In Eritrea, during 1996, two separate epizootics of FMD occurred. ERI/1/96 clustered as part of branch $A 1$, while $\mathrm{ERI} / 2 / 96$ clustered as part of branch A3.

FMD viruses that differ between 2-7\% from each other are generally believed to originate from the same epizootic (Samuel, Knowles, Kitching \& Hafez 1997; Bastos 2001). This defined percentage difference was used to evaluate the epizootics occurring in Ethiopia. The historical viruses indicated that the FMD outbreaks of 1993 and 1979 in Ethiopia were unrelated, as the 1983 isolate, ETH/19/77, clustered in branch A1 while the 1979 strains clustered in A2. Surprisingly, the 1979 strain clustered with a strain that was isolated 13 years later in 1992, supported by $89 \%$ bootstrap support, but they are probably not part of the same epizootic (differed by $>7 \%$ ). In addition, three viruses from 1990 were responsible for one outbreak, viz. ETH/3/90, ETH/8/90 and ETH/12/90 (branch A1), while in 2001, ETH/16/01 and $\mathrm{ETH} / 22 / 01$ were responsible for one epizootic 
and $\mathrm{ETH} / 15 / 01$ for another (branch $\mathrm{A} 1$ ) in Ethiopia. For each of these epizootics it was shown that the viruses differed from each other by no more than $7 \%$ across the nucleotide region characterized in this study.

The three outbreak strains isolated during 1994 were not closely related to one another (Fig. 1). Although ETH/24/94 and ETH/8/94 clustered as part of branch $A 1$, they differed by $9 \%$ from each other and clustered on separate branches within branch $\mathrm{A} 1$, while $\mathrm{ETH} / 30 / 94$, differed by $10 \%$ from these viruses and clustered in a separate branch, A3. The 1995 Ethiopian isolate, ETH/5/95 differed by only $4.6 \%$ from its nearest neighbour, ETH/19/77, the vaccine strain. This indicated that this 1995 outbreak in Ethiopia may have been due to the vaccine not being completely inactivated when administered to cattle. Due to the under-reporting of FMD outbreaks, the clustering profile observed might not be a true reflection of the field situation.

Despite having been sampled over a period of 22 years the Ethiopian, Kenyan and Eritrean isolates showed a group mean divergence percentage between $11.6-13 \%$. This close genetic relationship of isolates from these three countries suggests that trans-border movement is a major cause for disease dissemination. One could speculate that the sharing of clades between countries or the confinement of certain clades to a specific country could be largely influenced by the social, economic, climatic and political situation in that area at any given point in time.

In a previous study (Sangare et al. 2001), the Kenyan isolates were the only representative viruses from East Africa. Samuel \& Knowles (2001) reported that Kenyan and Ugandan isolates form part of the East African topotype, while viruses from other East African countries, viz. Tanzania, Eritrea and Ethiopia form part of the Middle East-South Asia topotype. Contrary to that study we have showed that the Ethiopian, Eritrean and Kenyan isolates form part of the East African topotype. An intensive study encompassing all East African countries to clarify the topotypes present in this region is currently being undertaken by the authors.

Differences in the genetic composition of viruses from the same serotype do not necessarily reflect differences in antigenicity (Esterhuysen 1994). On the other hand, it has also been shown that very limited genetic variations in the immunodominant region can alter the antigenic specificity of FMDV isolates (Mateu, Martìnez, Capucci, Andreu, Giralt,
Sobrino, Brocchi \& Domingo 1990; Mateu, Valero, Andreu \& Domingo 1996; Vosloo et al. 1996). Amino acid variability plots of the field isolates in comparison to the vaccine strain currently used in Ethiopia confirmed the genetic heterogeneity of the viral population. Such genetic differences, which may lead to antigenic changes, can cause vaccine failure and severe disease outbreaks. The effects of competition between viruses of the same serotype and the possibility of recombination could obviously cause quite marked effects on apparent genetic relationships, but its occurrence for FMDV in the field is less well established (Knowles \& Samuel 2003 and references therein).

The choice of FMD virus to be used as vaccine strain is important (Cartwright, Chapman \& Sharpe 1982) as the strain should be protective against a wide spectrum of different strains within the same serotype. The genetic variation at the nucleotide level of ETH/19/77 (vaccine strain) when compared to the recent outbreaks strains was only 7.1$11.6 \%$, but substitution of amino acids did occur in the immunodominant region of the $1 \mathrm{D}$ gene. This emphasizes the need to evaluate the immunogenic ability of the current vaccine against different field isolates.

\section{ACKNOWLEDGEMENTS}

We thank N. Ferris of the Animal Health Institute, Pirbright, UK for supplying the majority of the viruses used in this study. We are also very grateful to all technical staff of Exotic Diseases Division of the Onderstepoort Veterinary Institute for their technical assistance. Particular thanks must be expressed to C.I. Boshoff, H.G. van Rensburg and A.D.S. Bastos for valuable discussions. M. Sahle's Ph.D. studies were supported by the National Veterinary Institute, Ethiopia, Intervet and THRIP.

\section{REFERENCES}

ANONYMOUS. 1976. FAO-WHO-OIE animal health yearbook 1976, edited by H.O. Konigshofer. Rome, Italy: Food and Agriculture Organization.

ANONYMOUS. 1998. Strategy document on animal health research. National Animal Health Research Center (NAHRC), Ethiopia.

ANONYMOUS. 2000. Federal Democratic Republic of Ethiopia Central Statistical Authority, Statistical Abstract, 2000. Addis Ababa.

BASTOS, A.D. 1998. Detection and characterization of foot-andmouth disease in sub-Saharan Africa. Onderstepoort Journal of Veterinary Research, 65:37-47. 
BASTOS, A.D.S., BOSHOFF, C.I., KEET, D.F., BENGIS, R.G. \& THOMSON, G.R. 2000. Natural transmission of foot-andmouth disease virus between African buffalo (Syncerus caffer) and impala (Aepyceros melampus) in the Kruger National Park, South Africa. Epidemiology and Infection, 124:591598.

BASTOS, A.D. 2001. Molecular epidemiology and diagnosis of SAT type foot-and-mouth disease in southern Africa. Ph.D. thesis, University of Pretoria.

BASTOS, A.D. \& SANGARE, O. 2001. Geographic distribution of SAT-2 type foot-and-mouth disease virus genotypes in Africa, in Proceedings of the Southern Africa Society for Veterinary Epidemiology and Preventive Medicine (SASVEPM), Pretoria: 20-26.

BECK, E. \& STROHMAIER, K. 1987. Subtyping of European FMDV outbreak strains by nucleotide sequence determination. Journal of Virology, 61:1621-1629.

BERSON, J.P., COLSON, X., FIKRE, J., VIGIER, M., ASSEFA W.G., GUERCHE, J., BLANC, R. \& PRUNET, P. 1972. Epidemiological study of foot-and-mouth disease in Ethiopia (1969-1971). Bulletin de l'Office International des Epizooties, 77:595-620.

BRÜCKNER, G.K., VOSLOO, W., DU PLESSIS, B.J., KLOECK, P.E., CONNOWAY, L., EKRON, M.D., WEAVER, D.B., DICKASON, C.J., SCHREUDER, F.J., MARAIS, T. \& MOGAJANE, M.E. 2002. Foot and mouth disease: the experience of South Africa. Scientific and Technical Review, Office International des Epizooties, 21:751-764.

BOOM, R., SOL, C.J., SALIMANS, M.M.M., JANSEN, C.L., WERTHEIM-VAN DILLEN, P.M.E. \& VAN DEN NOORDAA J. 1990. Rapid and simple method for purification of nucleic acids. Journal of Clinical Microbiology, 28:495-503.

CARTWRIGHT, B., CHAPMAN, W.G. \& SHARPE, R.T. 1982. Stimulation of heterotypic antigen of foot-and-mouth disease virus antibodies in vaccinated cattle. Research in Veterinary Science, 32:338-342.

CONDY, J.B., HEDGER, R.S., HAMBLIN, C. \& BARNETT, I.T.R 1985. The duration of the foot and mouth disease carrier state in African buffalo (I) in the individual animal and (II) in a free living herd. Comparative Immunology, Microbiology and Infectious Diseases, 8:259-265.

DAWE, P.S., FLANAGAN, F.O., MADEKUROZWA, R.L., SORENSEN, K.J., ANDERSON, E.C., FOGGIN, C.M., FERRIS, N.P. \& KNOWLES N.J. 1994. Natural transmission of foot-and-mouth disease from African buffalo (Syncerus caffer) to cattle in a wildlife area of Zimbabwe. The Veterinary Record, 134:230-232.

ESTERHUYSEN, J.J. 1994. The antigenic variation of foot-andmouth disease viruses and its significance in the epidemiology of the disease in southern Africa. M.Sc. thesis, University of Pretoria.

FREIBERG, B., RAHMAN, M.M., MARQUARDT, O. 1999. Genetical and immunological analysis of recent Asian type $A$ and $O$ foot-and-mouth disease virus isolates. Virus Genes, 19: 167-182.

FIKRE, J. 1975. Report of the Ethiopian delegation (to the OIE Commission on FMD). Bulletin de l'Office International des Epizooties, 83:51-53.

HAILE YESUS, T. 1988. Animal health in Ethiopia, in Animal health problems in selected African countries. Report of a technical consultation in Lusaka, Zambia, 23-28 November 1987: 46-60

HARLEY, E.H. 2001. DAPSA, DNA and Protein Sequence Analysis, version 2.91. Department of Chemical Pathology, University of Cape Town, South Africa.
HEDGER, R.S. 1972. Foot and mouth disease and the African buffalo (Syncerus caffer). Journal of Comparative Pathology, 82:19-28.

HEDGER, R.S., CONDY, J.B. \& GOLDING, S.M. 1972. Infection of some species of African wildlife with foot and mouth disease virus. Journal of Comparative Pathology, 82:455-461.

HEDGER, R.S., FORMAN, A.J. \& WOODFORD, M.H. 1973. Foot-and-mouth disease in East African buffalo. Bulletin of Epizootic Diseases in Africa, 21:99-101.

HEDGER, R.S. 1976. Foot and mouth disease in wildlife with particular reference to the African buffalo (Syncerus caffer), in Wildlife diseases, edited by L.A. Page. New York, USA: Plenum Publishing Corporation.

KITCHING, R.P. 1998. A recent history of foot-and-mouth disease. Journal of Comparative Pathology, 118:89-108.

KITSON, J.D.A., McCAHON, D. \& BELSHAM, G.J. 1990. Sequence analysis of monoclonal antibody resistant mutants of type $\mathrm{O}$ foot and mouth disease virus; evidence for the involvement of the three surface exposed capsid proteins in four antigenic sites.Journal of Virology, 179:26-34.

KNOWLES, N.J. \& SAMUEL, A.R. 2003. Molecular epidemiology of foot-and-mouth disease virus. Virus Research, 91:6580

KUMAR, S., TAMURA, K. \& NEI, M. 1993. MEGA. Molecular Evolutionary Genetics Analysis. Version 1.02. Pennsylvania State University, USA.

KUMAR, S., TAMURA, K., JAKOBSEN, I. B. \& NEI, M. 2001. MEGA 2: Molecular Evolutionary Genetics Analysis Software. Tempe, Arizona, USA: Arizona State University.

MARTEL, J.L. 1974. Foot-and-mouth disease in Ethiopia. Distribution of viral serotypes. Revue d'Elevage et de Medecine Veterinaire des Pays Tropicaux, 27:169-175.

MARTEL, J.L. \& GALLON, C. 1975. Comparative serological study of the principal foot-and-mouth disease virus strains isolated in Ethiopia, 1969-1974. Revue d'Elevage et de Medecine Veterinaire des Pays Tropicaux, 28:287-295.

MATEU, M.G., MARTINNEZ, M.A., CAPUCCI, L., ANDREU, D., GIRALT, E., SOBRINO, F., BROCCHI, E. \& DOMINGO, E. 1990. A single amino acid substitution affects multiple overlapping epitopes in the major antigenic site of foot-andmouth disease virus of serotype C. Journal of General Virology, 71:629-637.

MATEU, M.G., VALERO, M.L., ANDREU, D. \& DOMINGO E.1996. Systematic replacement of amino acid residues within an Arg-Gly-Asp-containing loop of foot-and-mouth disease virus and effect on cell recognition. Journal of Biological Chemistry, 271:12814-12819.

McDERMOTT, J.J. \& ARIMI, S.M. 2002. Brucellosis in subSaharan Africa: Epidemiology, control and impact. Veterinary Microbiology, 90:111-134.

MENGISTU, A. 1997. Conservation-based forage development for Ethiopia. Self-help Development International Institute for Sustainable Development, Addis Ababa.

MERSIE, A., TAFESSE, B, GETAHUN, F \& TEKLU, W. 1992. Losses from foot-and-mouth disease in a mixed farming area of eastern Ethiopia. Tropical Animal Health and Production, 24:144.

RODRIGUEZ, A., NUNEZ, J.I., NOLASCO, G., PONZ, F., SOBRINO, F. \& DE BLAS, C. 1994. Direct PCR detection of foot-and-mouth disease virus. Journal of Virological Methods, 47:345-349. 
ROEDER, P.L., ABRAHAM, G., MEBRATU, G.Y. \& KITCHING, R.P. 1994. Foot-and-mouth disease in Ethiopia from 1988 to 1991. Tropical Animal Health and Production, 26:163-167.

SAIZ, J.C., SOBRINO, F. \& DOPAZO, J. 1993. Molecular epidemiology of foot-and-mouth disease virus type $\mathrm{O}$. Journal of General Virology, 74:2281-2285.

SAMUEL, A.R. \& KNOWLES, N.J. 2001. Foot-and-mouth disease type $O$ viruses exhibit genetically and geographically distinct evolutionary lineages (topotypes). Journal of General Virology, 82:606-621.

SAMUEL, A.R., KNOWLES, N.J., KITCHING, R.P. \& HAFEZ, S.M. 1997. Molecular analysis of type $O$ foot-and-mouth-disease viruses isolated in Saudi Arabia between 1983 and 1995. Epidemiology \& Infection, 119:381-389.

SANGARE, O., BASTOS, A.D.S., MARQUARDT, O., VENTER, E.H., VOSLOO, W. \& THOMSON, G.R. 2001. Molecular epidemiology of serotype $\mathrm{O}$ foot-and-mouth disease virus with emphasis on West and South Africa. Virus Genes, 22:343349.

THOMSON, G.R. 1994. Foot-and-mouth disease, in Infectious diseases of livestock with special reference to Southern Africa, edited by J.A.W. Coetzer, G.R. Thomson \& R.C. Tustin, Cape Town: Oxford University Press Southern Africa.

THOMSON, G.R. 1996. The role of carrier animals in the transmission of foot and mouth disease, in Comprehensive Reports on Technical Items presented to the International
Committee or to Regional Commissions, 1996. Office International des Epizooties, Paris: 87-103.

THOMSON, G.R. 2001. Alternatives for controlling animal diseases resulting from interactions between livestock and wildlife in southern Africa. South African Journal of Science, 95:71-76.

THOMSON, G.R., VOSLOO, W. \& BASTOS, A.D.S. 2003. Foot and mouth disease in wildlife. Virus Research, 91:145-161.

VOSLOO, W., BASTOS, A.D., KIRKBRIDE, E., ESTERHUYSEN, J.J., JANSE VAN RENSBURG, D., BENGIS, R.G. KEET, D.F. \& THOMSON, G.R. 1996. Persistent infection of African buffalo (Syncerus caffer) with SAT type foot-andmouth disease viruses: rate of fixation of mutations, antigenic change and interspecies transmission. Journal of General Virology, 77:1457-1467.

TSAI, C.P., PAN, C.H., LIU, M.Y., LIN, Y.L., CHEN, C.M., HUANG, T.S., CHENG, I.C., JONG, M.H. \& YANG, P.C. 2000. Molecular epidemiological studies on foot-and-mouth disease type O Taiwan viruses from the 1997 epidemic. Veterinary Microbiology, 74:207-216.

VOSLOO, W., BASTOS, A.D.S., SANGARE, O., HARGREAVES, S.K. \& THOMSON, G.R. 2002. Review of the status and control of foot and mouth disease in sub-Saharan Africa. Scientific and Technical Review. Office International des Épizooties, 21:437-449. 